\title{
CORRESPONDENCE
}

\section{Temporal status of alkaline rocks of Deccan volcanic province and S. W. Rajasthan}

SIR - The Deccan volcanic province covering an area of approximately $600000 \mathrm{Sq} . \mathrm{Km}$. consists chiefly of tholeiitic basalts. The true alkali basalts and other alkaline rocks are restricted in the western and northwestern part of the province in the form of plug-like bodies, and minor intrusions along two or three volcano tectonic belts. The chief occurrences are Barwaha, Ambadongar, Pavagarh, Netrang, Girnar and Barda along the E-W trending Narmada lineament and its easterly extension and Mundwara, Kadi, and Jawahar along the $\mathrm{N}-\mathrm{S}$ trending Rajasthan-Gujrat rift and West Coast rift (Bose, 1980). Besides Mundwara, there are several other occurrences of alkaline rocks in Sirohi, Jalore, Barmer and Jodhpur districts of Rajasthan. There is a general consensus among workers that alkaline magmatism in the Deccan volcanic province was manifested towards the closing phase of igneous activity. According to Mathur, Dubey \& Sharma (1926) the Mount Girnar complex was emplaced within the Deccan Trap and was also partly contemporaneous with them.

The majority of K-Ar ages reported for the Deccan volcanics are in the range 60-65 Ma, but the age of Deccan activity remains a controversial issue mainly because cases of excess radiogenic ${ }^{40} \mathrm{Ar}$ and loss of radiogenic ${ }^{40} \mathrm{Ar}$ are known (Kanoeka \& Haramura, 1973; Wellman \& McElhinny, 1970; Agarwal \& Rama, 1976; Paul et al. 1977; Balasubrahmanyan \& Snelling, 1981) making the calculated ages too old and too young respectively. The oldest ages which may be reliable for limited areas of Deccan volcanics are ${ }^{40} \mathrm{Ar} /{ }^{39} \mathrm{Ar}$ dates reported by Kaneoka (1980) falling in the range 70-80 Ma. Such relatively older ages are also in accord with palaeontological opinion. Govindan (1981) concluded on the basis of study of foraminifers that in the Narsapur Well-1 (Godavari basin, East Coast) the trap activity closed at late Maastrichtan age and the post trappean sediments are of definite Palaeocene age. Amongst the younger ages, the ages determined on Girnar complex (supposedly forming part of Deccan Trap activity) are probably the least ambiguous estimates of the age, $c$. 62-65 Ma. The ages for Pavagarh volcanics are also in the same range.

The duration of Deccan activity is also a controversial issue, largely because a number of younger $\mathrm{K}-\mathrm{Ar}$ ages down to $30 \mathrm{Ma}$ (Alexander, 1981) have been reported. Most of these young ages are unreliable and undoubtedly represent radiogenic ${ }^{40} \mathrm{Ar}$ loss from the dated whole rock sample (Valsangkar, et al. 1981). Further, there is palaeomagnetic evidence that extrusion of most of the Deccan lava occurred in a short time interval probably about 5 Ma (McElhinny, 1968) because only one major polarity reversal from reversed to normal has been identified. According to Karmarkar (1978) and West (1981) the geomorphic evidence is against the traps being erupted over a long time interval and for the eruption taking place in relatively rapid succession giving little time for erosion.

If we accept on the basis of the foregoing discussion, and the palaeontological evidence, that the main outpouring of the Deccan Trap was not younger than $70 \mathrm{Ma}$ and not older than $80 \mathrm{Ma}$, then the alkaline rocks associated with Deccan activity (Girnar, Pavagarh etc.) mark a younger phase of palaeocene activity and the $56 \pm 8$ Ma fission track date of the Mer ring of Mundwara (Subrahmanyan, Murali \& Rao, 1972) comes within this activity. The nepheline syenite of Sarnu, Jodhpur, Rajasthan (reported by La Touche, 1902, in his memoir on the geology of western Rajputana and described by Holland on page 92 of the same memoir) which is intrusive in the Barmer sandstone of Cretaceous age and is similar to sodalite monzonite of Mundwara, also probably belongs to same phase of alkaline activity.

The cause of this Palaeocene volcanic activity is to be found in the northward movement of the Indian plate. According to Bose (1980) and northward-moving Indian plate developed special volcano-tectonic setting by crustal warping. A set of fractures trending $\mathrm{N}-\mathrm{S}$ was accentuated by shear and the other major trending E-W to NW-SE was favoured by tensional forces, resulting in re-activation of ancient Narmada lineament, the Gujrat-Rajasthan and the West Coast fault and also probably a large number of $\mathrm{N}-\mathrm{S}$ trending parallel faults in south-western Rajasthan. According to Thomson \& Melson (1972) magmatic activity subsequent to rifting could assume an alkaline nature. In this context it would also be interesting to investigate if there are younger intrusives along the

Geol. Mag. 120 (3), 1983, pp. 303-304. Printed in Great Britain. 
great-boundary fault between Arawali and Vindhyans which may be an ancient lineament. Some of the known occurrences which may be related to re-activation of this ancient lineament in Palaeocene time are gabbroic rocks in the village of Hora, District Chittorgarh, Rajasthan, and the alkali olivine dolerite dyke at Zawar, Udaipur District, Rajasthan.

\section{References}

Agarwal, J. K. \& Rama. 1976. Chronology of Mesozoic volcanics of India: Proc. Indian Acad. Sci. 84, $157-79$.

Alexander, P. O. 1981. Age and duration of Deccan volcanism: K-Ar evidence. Mem. geol. Soc. India 3, 244-58.

Balasubrahmanyan, M. N. \& Snelling, N. J. 1981. Extraneous argon in lavas and dykes of Deccan Traps. Mem. geol. Soc. India 3, 259-64.

Bose, M. K. 1980. Alkaline magmatism in Deccan volcanic province. J. geol. Soc. India 21, 317-29.

Govindan, A. 1981. Forminifera from infra and inter trappean subsurface sediments of Narsapur Well-1 and age of Deccan Trap flows. In Proc. IX Indian Coll. Micropal. Strat. (ed. S. C. Khosla and R. P. Kachara), pp. 81-93. Udaipur, India: Department of Geology, Rajasthan University.

Kaneoka, I. 1980. ${ }^{40} \mathrm{Ar} /{ }^{39} \mathrm{Ar}$ dating of volcanic rocks of Deccan Traps, India. Earth Planet. Sci. Lett. 46, 233-43.

Kaneoka, I. \& Haramura, H. 1973. K-Ar ages of successive lava flows from the Deccan Traps, India. Earth Planet. Sci. Lett. 8, 229-36.

Karmarkar, B. M. 1978. The Deccan Trap basalt flows of the Bor Ghat Section of central railways. J. geol. Soc. India 19, 106-14.

La Touche, T. D. 1902. Geology of western Rajputana. Mem. Geol. Surv. India 35, part I, 78-93.

Mathur, K. K., Dubey, V. S. \& Sharma, N. L. 1926. Magmatic differentiation in Mount Girnar. J. Geol. 34, 289-307.

McElhinny, M. W. 1968. Northward drift of India - Examination of recent paleomagnetic results. Nature, Lond. 217, 342-44.

Paul, D. K., Potts, P. J., Rex, D. C. \& Beckinsale, R. D. 1977. Geochemical and petrogenetic study of the Girnar complex, Deccan volcanic province, India. Bull. geol. Soc. Am. 88, 277-84.

Subrahmanyan, N. P., Murali, A. V. \& Rao, G. V. U. 1972. Age of Mundwara igneous complex, Rajasthan. Curr. Sci. 41, 63-64.

Thomson, G. \& Melson, W. G. 1972. The petrology of oceanic crust across fracture zones in the Atlantic ocean: Evidence of a new kind of sea floor spreading. J. Geol. 80, 526-38.

Valsangkar, A. B., Radhakrishnamurty, C., Subbarao, K. V. \& Beckinsale, R. D. 1981. Paleomagnetism and $\mathrm{K}-\mathrm{Ar}$ age studies of acid igneous rocks from St Mary islands. Mem. geol. Soc. India 3, 265-76.

Wellman, P. \& McElhinny, M. W. 1970. K-Ar age of Deccan Traps of India. Nature, Lond. 227, 595-96.

West, W. D. 1981. Duration of Deccan Trap activity. Mem. geol. Soc. India 3, 277-78.

R. K. SRIVASTAVA

Department of Geology

University of Rajasthan

Udaipur

India

20th August 1982 